may not be certain exactly where title rests; and (c) that when single items or very small collections are involved, donors often do not wish to become involved in library gift procedures.

2. Many libraries still accept temporary deposits. As a general principle, such gifts ordinarily should not be accepted unless (a) the library has reason to believe that a temporary deposit is the only way in which the material is likely to be preserved; or (b) the library has reason to believe that a temporary deposit will in time be changed to a permanent gift; or (c) except where ownership of corporate records is governed by state and/or federal regulations.

3. Ordinarily transfer of legal title by gift is accomplished by a properly executed form, variously described as "Instrument of Gift" or "Certificate of Gift." This form should include the following: (a) name and address of the donor; (b) description of the gift; (c) statement of transfer of legal title, and where possible and applicable, copyrights and literary rights; (d) any restrictions; (e) directions concerning disposal of unwanted items.

The form must be (1) signed and dated by the donor and (2) witnessed and dated by another party who is neither related to the donor nor employed by the institution receiving the gift.

An additional evidence of proof would be the notarization of the donor's and witnesses' signatures.

(Reprints of the above statements are available from ACRL, 50 E. Huron St., Chicago, IL 60611. Single copies are free of charge. Multiple copies are twenty cents (20ф) each.)

\title{
Statement of the American Library Association's Policy on Federal Legislation Regarding College and Research Libraries
}

Adopted by ALA Council

January 26, 1973

Washington, D.C.

As a vital part of higher education, library resources and services must be strengthened and expanded to meet the increases in student enrollment and to support new and changing programs of instruction and research. Increased support of university, college, and junior college libraries must be a part of increased funding of higher education. Any federal legislation which stimulates new or expanded educational programs should provide sufficient additional funds to meet the library material and personnel needs required for the success of these programs.

Substantial financial aid is needed by libraries in the nation's developing institutions if they are to overcome the many years in which they received little or no financial aid to support their educational programs. At the same time, major research libraries of the country need substantial financial aid if they are to continue to acquire the vast product of worldwide scholarship and make it available beyond their own academic communities.

Funds for library materials and personnel, federal scholarships and loans, special grants, research grants and contracts, assistance in building programs, and tax exemptions for ed- ucational institutions benefit the nation by improving the quality of higher education. The Higher Education Act has contributed immeasurably to the improvement of higher education by providing funds for library resources and facilities.

The Task Force on the Status of Women in Librarianship is interested in obtaining information on the placement services of the accredited graduate library schools in the United States. At the beginning of January, a brief questionnaire was directed to the chief administrator of each program. While replies will be kept confidential, plans are being made to tabulate the results. Persons wishing a copy of the questionnaire (e.g. unaccredited programs, Canadian, and other schools) may direct requests to Helen Rippier Wheeler, Associate Professor, School of Library Science, Louisiana State University, Baton Rouge, LA 70803. The Task Force on the Status of Women in Librarianship, Michelle Rudy, Coordinator, is a part of the Social Responsibilities Round Table. 